\title{
Relation between some folate-dependent metabolic pathways and dietary folate content in chicks
}

\author{
BY COLIN C. WHITEHEAD AND J.SARAH RENNIE \\ AFRC Institute for Grassland and Animal Production, Roslin, Midlothian EH25 9PS
}

(Received 12 December 1988 - Accepted 20 February 1989)

\begin{abstract}
Responses of several folate-metabolizing pathways to dietary folic acid were studied in 2-week-old chicks. Oxidation of a histidine load to carbon dioxide was impaired in folate-deficient chicks. There was a curvilinear relation between oxidation and dietary folate, and maximum oxidation occurred with $\mathbf{2} \mathbf{~ m g}$ supplemental folic acid $/ \mathrm{kg}$. Hepatic activities of glutamic acid formiminotransferase $(E C 2.1 .2 .5)$ and glycine $N$-methyltransferase (EC 2.1.1.20) were not affected significantly $(P>0.05)$ by dietary folic acid. The activity of dihydrofolate reductase $(E C 1.5 .1 .3)$ in erythrocytes was elevated in folatedeficient chicks. These studies show that the activities of two folate-dependent pathways can be used as biochemical criteria of folate status in chicks.
\end{abstract}

Dietary folate: Folate-dependent metabolic pathways: Chicken.

Specific metabolic criteria of status can be very helpful for assessing requirements for individual vitamins in poultry. For instance, pyruvate carboxylase $(E C 6.4 .1 .1)$ and glutathione reductase $(E C 1.6 .4 .2)$ have provided useful information on the status and requirements of young chickens or turkeys for biotin (Whitehead \& Bannister, 1978) and riboflavin (Lee, 1982) respectively. However, comparable criteria are lacking in the case of folic acid.

Previous studies (Maxwell et al. 1988) have identified haematological abnormalities in folate-deficient chicks and found that the dietary folate levels needed to prevent some of these abnormalities were higher than current estimates of chick folate requirements (National Research Council, 1984). However, these haematological abnormalities may not have been completely specific for folate status. The studies also established relations between blood and dietary folate levels.

Metabolic pathways directly dependent on folate might provide more specific information on folate status. Burns \& Jackson (1976) have reported altered activities of some folate-metabolizing enzymes in livers from folate-deficient chicks. The present report describes the results of further investigations on the effect of folate deficiency on several folate-dependent pathways in chicks and the response of these pathways to graded dietary supplements of folate.

\section{MATERIALS AND METHODS}

\section{Birds and husbandry}

Male broiler chicks (1-d-old; D. B. Marshall Ltd, Newbridge, Midlothian) were allocated at random to five dietary treatments. The basal folate-deficient diet was similar to the low vitamin casein - gelatin - wheat-starch diet A previously used by Maxwell et al. (1988) with the addition (/ $\mathrm{kg}$ diet) of L-arginine $(2 \cdot 7 \mathrm{~g}), \mathrm{L}$-tryptophan $(130 \mathrm{mg})$ and L-cystine $(520 \mathrm{mg})$ to improve its amino acid balance. Four other diets were derived from the basal diet by supplementation with $1,1 \cdot 5,2$ or $4 \mathrm{mg}$ folic acid $/ \mathrm{kg}$ using a commercial preparation containing $800 \mathrm{~g}$ folic acid $/ \mathrm{kg}$ on a dextrin support (Rovimix Folic $80 \mathrm{SD}$; Hoffmann-La Roche, Basle). The level of $4 \mathrm{mg} / \mathrm{kg}$ was considered to be an adequate control in relation 
to the estimated requirement of $0.55 \mathrm{mg} / \mathrm{kg}$ (National Research Council, 1984). The chicks were housed in compartments of wire-floored electrically heated tier brooders and had unrestricted access to food and water. They were reared in several batches until approximately $14 \mathrm{~d}$ of age when they were used in the following studies.

\section{Reagents}

Radiochemicals were obtained from Amersham International plc, Amersham, Bucks. The specific activities of L- $\left[1-{ }^{14} \mathrm{C}\right]$ histidine, $S$-adenosyl-L-[methyl- $\left.{ }^{14} \mathrm{C}\right]$ methionine and $\left[3^{\prime}, 5^{\prime}, 7^{\prime}, 9^{\prime}\right.$ $\left.{ }^{3} \mathrm{H}\right]$ pteroylmonoglutamic acid were $56 \mathrm{mCi} / \mathrm{mmol}, 0.5 \mathrm{mCi} / \mathrm{mmol}$ and $51 \mathrm{Ci} / \mathrm{mmol}$ respectively. All other reagents were of analytical or scintillation grade.

\section{Histidine oxidation}

These experiments were performed using a metabolism chamber and carbon dioxidetrapping system of ethanolamine: 2-methoxyethanol described by Saunderson \& Whitehead (1987). In a preliminary experiment to compare rates of oxidation, one bird from each of the diets containing 0 and $4 \mathrm{mg}$ supplemental folic acid $/ \mathrm{kg}$ was injected intraperitoneally with a dose of $4 \mu \mathrm{Ci} \mathrm{L}-\left[1-{ }^{14} \mathrm{C}\right]$ histidine $/ \mathrm{kg}$ body-weight, contained in $0 \cdot 258$ M-L-histidine $(10 \mathrm{ml} / \mathrm{kg}$ body-weight $)$. Each bird was placed in the chamber and the trapping solution was changed every $30 \mathrm{~min}$ over a $3 \mathrm{~h}$ collection period. The ${ }^{14} \mathrm{CO}_{2}$ collected in the solution was measured as described by Saunderson (1985).

In the main experiment, between ten and fifteen birds, representing each of the five treatments, were injected intraperitoneally with $1 \mu \mathrm{Ci}$ labelled histidine $/ \mathrm{kg}$ in the same dose of unlabelled histidine as before. Evolved ${ }^{14} \mathrm{CO}_{2}$ was collected for $1.5 \mathrm{~h}$, with the trapping solution being changed at 15 min intervals.

A pair-feeding experiment was carried out on birds fed on the basal and control diets. The chicks were fed ad lib. as before for 1 week and then transferred to individual small wire cages in a heated room. The birds were allocated to six groups of three birds on the basis of similar body-weight. In each group, two birds continued to be fed on the basal and control diets ad lib., while the third bird remained on the control diet but was pair-fed with the bird given the basal diet. Histidine oxidation was measured as before when the birds were approximately $14 \mathrm{~d}$ old.

\section{Enzyme activities}

Dihydrofolate reductase (EC 1.5.1.3; DHFR) activity was measured in erythrocytes. Blood samples $(0.5 \mathrm{ml})$ were taken from each chick by heart puncture using heparin as an anticoagulant. After centrifugation the plasma and leucocyte layer were drawn off and the erythrocytes were resuspended in ice-cold saline $(9 \mathrm{~g}$ sodium chloride $/ 1 ; 1.5 \mathrm{ml})$. This process was repeated twice more. The erythrocytes were finally suspended in $0.05 \mathrm{M}$-sodium citrate $(0.3 \mathrm{ml})$ at $\mathrm{pH} 7.2$ and $0^{\circ}$. A small portion of this solution was taken for cell counting using a Coulter counter. The cells in the remainder of the solution were lysed by freezethawing twice and insoluble debris was removed by centrifugation at $20000 \mathrm{~g}$ for $30 \mathrm{~min}$ at $4^{\circ}$.

DHFR was measured by the method of Rothenberg et al. (1980) with slight modifications. ${ }^{3} \mathrm{H}$-labelled folic acid $(50 \mathrm{pmol})$ was added to $250 \mu \mathrm{l}$ of a solution of sodium citrate $(0.05 \mathrm{M})$, mercaptoethanol $(0.01 \mathrm{M})$ and sodium dithionite $(6 \mathrm{~mm})$ at $\mathrm{pH} 7.2$ in $1.5 \mathrm{ml}$ capped Eppendorf tubes. This mixture was incubated at $37^{\circ}$ for $15 \mathrm{~min}$. The erythrocyte preparations $(40 \mu \mathrm{l})$ and NADPH $(50 \mu \mathrm{l}, 1.3 \mathrm{~mm})$ were then added to each tube. A blank did not contain any erythrocyte preparation. The volume in each tube was made up to $500 \mu 1$ with a solution of sodium citrate $(0.05 \mathrm{~m})$ and mercaptoethanol $(0.01 \mathrm{~m})$ at $\mathrm{pH} 7 \cdot 2$. The reaction was stopped by the sequential addition of $200 \mu 1$ freshly prepared $0.027 \mathrm{M}$-folic acid in $0.1 \mathrm{M}$-sodium hydroxide, $100 \mu \mathrm{l} 0.2 \mathrm{M}$-hydrochloric acid and $200 \mu \mathrm{l} 0.3 \mathrm{M}$-zinc 
sulphate to precipitate selectively both unconverted $\left[{ }^{3} \mathrm{H}\right]$ folic acid and unreacted $\left[{ }^{3} \mathrm{H}\right]$ dihydrofolic acid. After removal of folate and protein precipitates by centrifugation, a $100 \mu \mathrm{l}$ portion of supernatant fraction was added to $5 \mathrm{ml}$ Optiphase $\mathrm{X}$ for scintillation counting. The coefficient of variation of repeat measurements using this method was $5 \cdot 7 \%$.

Glycine $N$-methyltransferase $(E C 2 \cdot 1 \cdot 1.20 ;$ GNMT) and glutamic acid formiminotransferase (EC 2.1.2.5; GFT) activities were measured in liver samples. The chicks were killed by cervical dislocation and livers were removed and frozen quickly to $-20^{\circ}$. Homogenates for both assays were prepared by homogenizing $0.5 \mathrm{~g}$ frozen liver with 2.5 $\mathrm{ml}$ ice-cold $10 \mathrm{~mm}$-potassium phosphate and $1 \mathrm{~mm}$-EDTA at $\mathrm{pH} 7.2$ using a Polytron homogenizer. This homogenate was used directly in the assay for GFT (Tabor, 1962). For GNMT, the homogenate was centrifuged at $10000 \mathrm{~g}$ for $30 \mathrm{~min}$ at $4^{\circ}$ and the supernatant fraction was assayed by the method of Cook \& Wagner (1984) modified by the use of $S$ adenosylmethionine labelled with ${ }^{14} \mathrm{C}$ instead of ${ }^{3} \mathrm{H}$. Protein contents of the preparations were measured by the method of Lowry et al. (1951). The coefficients of variation of repeat measurements were 5.7 and $2.1 \%$ for GFT and GNMT respectively.

\section{Statistical analysis}

Values were assessed using analysis of variance. Means for different treatments were compared using Student's $t$ test with pooled variance obtained from the analysis. The histidine-oxidation response curve was fitted to the individual values by a modified Newton method of maximizing the likelihood using standard non-linear models available in a Genstat package (Genstat, 1987).

\section{RESULTS}

Body-weights at 2 weeks of age of birds fed on the different diets are shown in Table 1. Birds fed on the basal diet were significantly $(P<0.05)$ lighter than those on all other diets, but differences between bird weights with the other diets were not significant $(P>0.05)$. As was also observed in an earlier study (Maxwell et al. 1988), growth depression on the basal diet did not occur until after $7 \mathrm{~d}$ of age.

\section{Histidine oxidation}

Results from the preliminary comparison of rates of oxidation of histidine showed marked differences between the folate-deficient and control chicks (Fig. 1). Over the $3 \mathrm{~h}$ collection period, $0.6 \%$ of administered radioactivity was released as ${ }^{14} \mathrm{CO}_{2}$ by the deficient birds compared with $1.4 \%$ by the control birds. Peak rate of release of ${ }^{14} \mathrm{CO}_{2}$ was shown by the control after $1.5 \mathrm{~h}$ and this was taken as the collection time in the main experiment.

The percentages of label released as ${ }^{14} \mathrm{CO}_{2}$ by birds fed on different dietary levels of folate in the main experiment are given in Table 1. There was a significant $(P<0.05)$ suppression in release of ${ }^{14} \mathrm{CO}_{2}$ by birds fed on the basal diet. The dose-response relation was investigated and an asymptotic curve with the equation given in Fig. 2 was found to give the best fit $\left(R^{2} 0 \cdot 5\right)$. This curve suggested that about $2 \mathrm{mg}$ supplemental folate $/ \mathrm{kg}$ were needed for the maximum rate of catabolism of histidine to $\mathrm{CO}_{2}$.

In the pair-feeding experiment, the mean percentages of label released as ${ }^{14} \mathrm{CO}_{2}$ in $1.5 \mathrm{~h}$ were 6.38 (SE 0.71), 9.67 (SE 0.65) and 11.49 (SE 1.33) for the groups given diets containing no supplemental folate, $4 \mathrm{mg}$ folate $/ \mathrm{kg}$ (pair-fed with the first group) and $4 \mathrm{mg}$ folate $/ \mathrm{kg}$ ad lib. The values for the latter groups given supplemental folate did not differ significantly $(P>0.05)$ from each other, but both were higher $(P<0.05)$ than the value for birds fed on the basal diet. 
Table 1. Body-weight, oxidation of histidine to carbon dioxide and activities of dihydrofolate reductase (EC 1.5.1.3; DHFR), glycine N-methyltransferase (EC 2.1.1.20;GNMT) and glutamic acid formiminotransferase (EC 2.1.2.5; GFT) at 2 weeks of age in chicks fed on a purified diet supplemented with graded levels of folic acid ${ }^{*}$

(No. of observations shown in parentheses)

\begin{tabular}{|c|c|c|c|c|c|c|}
\hline $\begin{array}{l}\text { Supplemental folic acid } \\
(\mathrm{mg} / \mathrm{kg}) \ldots\end{array}$ & 0 & 1 & $1 \cdot 5$ & 2 & 4 & $\begin{array}{c}\text { Standard } \\
\text { deviation } \\
\text { (from } \\
\text { ANOVA } \\
\text { table) }\end{array}$ \\
\hline Body-wt (g) & $146^{\mathrm{a}}$ & $200^{\mathrm{b}}$ & $208^{\mathrm{b}}$ & $181^{\mathrm{b}}$ & $207^{b}$ & 45 \\
\hline $\begin{array}{l}\text { Histidine oxidation } \\
(\% \text { of label released as } \\
\left.{ }^{14} \mathrm{CO}_{2} \text { in } 1.5 \mathrm{~h}\right)\end{array}$ & $\begin{array}{l}4 \cdot 67^{\mathrm{a}} \\
(13)\end{array}$ & $\begin{array}{l}8 \cdot 41^{\mathrm{b}} \\
(10)\end{array}$ & ${ }^{7 \cdot 13^{b}}$ & $\begin{array}{l}8 \cdot 75^{b} \\
(15)\end{array}$ & $\begin{array}{l}8 \cdot 66^{\mathrm{b}} \\
(13)\end{array}$ & $2 \cdot 62$ \\
\hline $\begin{array}{l}\text { DHFR (pmol } \\
\text { tetrahydrofolate } / 10^{9} \\
\text { erythrocytes in } 20 \mathrm{~min} \text { ) }\end{array}$ & $\begin{array}{l}0.51^{a} \\
(9)\end{array}$ & $\begin{array}{l}0 \cdot 28^{b} \\
(10)\end{array}$ & $\begin{array}{l}0 \cdot 32^{\mathrm{b}} \\
(5)\end{array}$ & $\begin{array}{l}0 \cdot 34^{b} \\
(6)\end{array}$ & $\begin{array}{l}0 \cdot 35^{\mathrm{h}} \\
(2)\end{array}$ & 0.14 \\
\hline $\begin{array}{l}\text { GNMT (nmol sarcosine/ } \\
\text { mg protein in } 15 \mathrm{~min} \text { ) }\end{array}$ & $\begin{array}{l}2 \cdot 00^{\mathrm{a}} \\
(5)\end{array}$ & $\begin{array}{l}2 \cdot 03^{a} \\
(8)\end{array}$ & $\begin{array}{l}1 \cdot 16^{\mathrm{a}} \\
(7)\end{array}$ & $\begin{array}{l}1 \cdot 46^{\mathrm{a}} \\
(8)\end{array}$ & $\begin{array}{l}1.47^{2} \\
(8)\end{array}$ & 0.73 \\
\hline $\begin{array}{l}\text { GFT }(\mu \mathrm{mol} 5,10- \\
\text { methylenetetrahydrofolate } / \\
\text { mg protein } / \text { min })\end{array}$ & $\begin{array}{l}4 \cdot 55^{\mathrm{a}} \\
(7)\end{array}$ & $\begin{array}{l}5 \cdot 70^{\mathrm{a}} \\
(9)\end{array}$ & $\begin{array}{l}5 \cdot 35^{\mathrm{a}} \\
(7)\end{array}$ & $\begin{array}{l}5 \cdot 35^{a} \\
(10)\end{array}$ & $\begin{array}{l}4 \cdot 95^{a} \\
(7)\end{array}$ & 0.85 \\
\hline
\end{tabular}

${ }^{a, b}$ Within a row, mean values with different superscript letters were significantly different $(P<0.05)$.

* For details of diets, see p. 203.

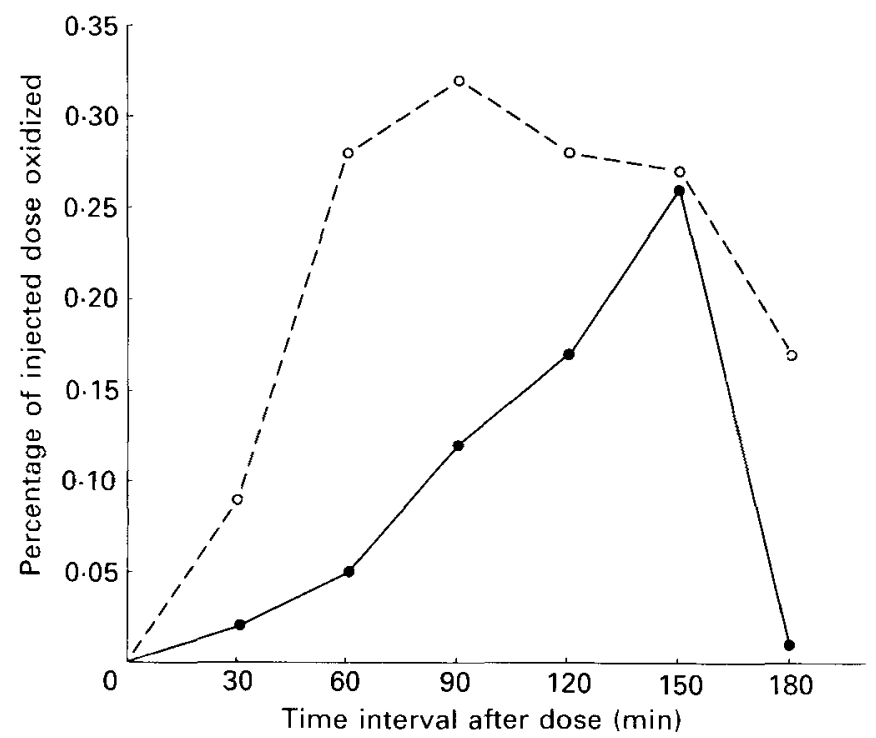

Fig. 1. Percentage of $\left[1{ }^{14} \mathrm{C}\right]$ histidine released as ${ }^{14} \mathrm{CO}_{2}$ by chicks fed on diets containing 0

( $\mathrm{O}--\mathrm{O}) \mathrm{mg}$ supplemental folic acid $/ \mathrm{kg}$ (one chick per treatment). For details of diets, see p. 203 


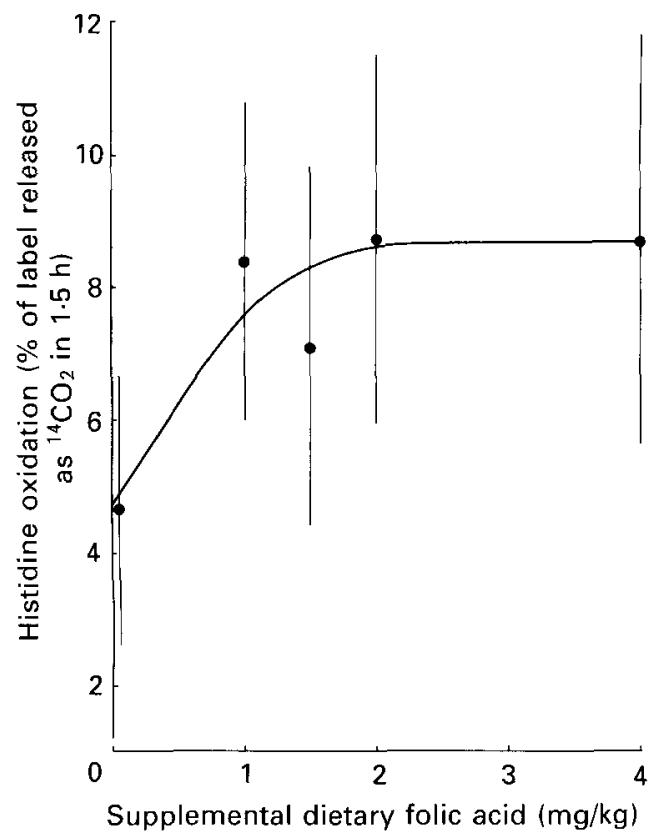

Fig. 2. Relation between histidine oxidation and dietary folic acid in chicks. Points are mean values for groups of chicks (standard deviations represented by vertical bars). The equation of the fitted curve is $Y=8.58-3.87$ $(0-24)^{x}$. For no. of chicks per treatment, see Table 1. For details of diets, see p. 203.

\section{Enzyme activities}

The specific activities for DHFR in erythrocytes and GFT and GNMT in liver are given in Table 1. DHFR activity was elevated significantly $(P<0.05)$ in the basal group. GFT and GNMT did not show any significant $(P>0.05)$ differences between treatments.

\section{DISCUSSION}

The conversion of $N$-formiminoglutamate (Figlu) to glutamate, catalysed by GFT, is the folate-dependent step in the oxidation of histidine. When folate is limiting, Figlu cannot be further metabolized by this route and the increased amount of it excreted in urine can be used as a measure of folate deficiency in mammals such as man and rats (Tabor et al. 1953; Luhby et al. 1959). This method is impractical in birds, but an alternative approach is to measure $\mathrm{CO}_{2}$ released from the 1-position of glutamate by oxidation. Folate deficiency should decrease the amount of ${ }^{14} \mathrm{CO}_{2}$ released following the administration of $\left[1-{ }^{14} \mathrm{C}\right]$ histidine as part of a histidine load. This response was indeed observed in the present experiment and is consistent with reports of altered patterns of histidine oxidation in other species, e.g. human beings (Fish et al. 1963).

Comparisons with pair-fed birds confirmed that the decreased release of label was caused by folate deficiency per se rather than by depressed feed intake or growth. The decrease in histidine oxidation was significant $(P<0.05)$ only for the basal diet, containing no added folate, but oxidation was also less with the diets containing 1 and $1.5 \mathrm{mg}$ folate $/ \mathrm{kg}$ than with the diet containing $4 \mathrm{mg}$ supplemental folate $/ \mathrm{kg}$. The response curve fitted to these values (Fig. 2) suggested that about $2 \mathrm{mg}$ supplemental folate $/ \mathrm{kg}$ was needed for the maximum rate of oxidation. The test, therefore, gives information on the folate status of 
chicks. However, since it involves the administration of about half the normal daily histidine intake in a single dose, it is not yet clear to what extent the test also indicates the normal folate requirement of the bird.

Although the oxidation of histidine via the pathway involving GFT is depressed by folate deficiency, the inhibition seems to be caused by a lack of tetrahydrofolate cofactor rather than to a decreased amount of GFT. Thus, measurement of hepatic GFT in vitro in a medium containing added folate did not show any effect of dietary folate level on the enzyme specific activity. This result is consistent with previous observations of Burns \& Jackson (1976).

GNMT is present in large amounts in mammalian liver: it makes up about $0.5 \%$ of the soluble protein in rat liver cytosol (Cook \& Wagner, 1981). It catalyses the $S$ adenosylmethionine-dependent conversion of glycine to sarcosine, but may also act as a carrier protein since it binds tightly to, and is inhibited by, 5-methyltetrahydrofolate (Cook \& Wagner, 1984). A deficiency of folate might, therefore, be expected to result in an increase in activity of this enzyme. Mean hepatic specific activities of GNMT were indeed found to be over $35 \%$ higher at the two lowest dietary levels of folate than at the highest, but these differences were not significant $(P>0.05)$. The high standard deviation (Table 1) suggests there is considerable biological variation in the activity of this enzyme.

DHFR is involved in the conversion of folic acid into one of the main metabolically active folates, tetrahydrofolate. The specific activity of this enzyme was significantly higher in the erythrocytes of chicks given no supplemental folic acid, but showed no differences between the supplemental diets. The elevated activity in the severely folate-deficient chicks is perhaps caused by a feed-back mechanism attempting to normalize reduced folate concentrations. However, this increase in activity of DHFR in erythrocytes contrasts with reported decreases in hepatic activity of DHFR in folate-deficient chicks (Burns \& Jackson, 1976) and rats (Pasquali et al. 1968). Burns \& Jackson (1976) speculated that folate deficiency decreased the concentration of DHFR in chick liver. To reconcile these opposite results, it is therefore necessary to propose that different mechanisms regulate this enzyme in erythrocytes and liver. Further studies are required before the value of DHFR as a criterion of folate status can be properly evaluated.

The results of these investigations confirm that biochemical criteria can be used to give information on folate status in chicks. Folate-metabolizing pathways involving the oxidation of histidine and DHFR seem to be particularly promising. However, before they can be used as a practical means of assessing status, further information is required on the range of dietary folate over which they respond, and influences of other dietary variables.

The authors are grateful to F. Hoffman-La Roche \& Co, Basle for financial support for this research and to Mrs P. Collings for statistical advice.

\section{REFERENCES}

Burns, R. A. \& Jackson, N. (1976). Effects of folate deficiency on some hepatic enzymes of folate metabolism in the oestrogen-treated female chick (domestic fowl). Biochemical Society Transactions 4, 914-917.

Cook, R. J. \& Wagner, C. (1981). Measurement of a folate binding protein from rat liver cytosol by radioimmunoassay. Archives of Biochemistry and Biophysics 208, 358-364.

Cook, R. J. \& Wagner, C. (1984). Glycine methyltransferase is a folate binding protein of rat liver cytosol. Proceedings of the National Academy of Sciences, USA 81, 3631-3634.

Fish, M. B., Pollycove, M. \& Feichtmeir, T. V. (1963). Differentiation between vitamin $B_{12}$-deficient and folic acid-deficient megaloblastic anaemias with ${ }^{14} \mathrm{C}$-histidine. Blood $21,447-461$.

Genstat (1987). Genstat 5 Reference Manual, p. 361. Oxford: Clarendon Press.

Lee, D. J. W. (1982). Growth, erythrocyte glutathione reductase and liver flavin as indicators of riboflavin status in turkey poults. British Poultry Science 23, 263-272. 
Lowry, O. H., Rosebrough, N. J., Farr, A. L. \& Randall, R. J. (1951). Protein measurement with the Folin phenol reagent. Journal of Biological Chemistry 193, 265-275.

Luhby, A. L., Cooperman, J. M. \& Teller, D. N. (1959). Urinary excretion of formiminoglutamic acid. Application in diagnosis of clinical folic acid deficiency. American Journal of Clinical Nutrition 7, $397-406$.

Maxwell, M. H., Whitehead, C. C. \& Armstrong, J. (1988). Haematological and tissue abnormalities in chicks caused by acute and subclinical folate deficiency. British Journal of Nutrition 59, 73-80.

National Research Council (1984). Nutrient Requirements of Poultry, 8th ed. Washington DC: National Academy Press.

Pasquali, P., Landi, L. \& Marchetti, M. (1968). Inter-relationships between folic acid and biotin: effect of biotin on the biosynthesis of folate coenzymes. Biochimica et Biophysica Acta 165, 561-563.

Rothernberg, S. P., Iqbal, M. P. \& DaCosta, M. (1980). A simplified radio-enzymatic assay for dihydrofolate reductase using $\left[{ }^{3} \mathrm{H}\right]$ dihydrofolate. Analytical Biochemistry 103, 152-156.

Saunderson, C. L. (1985). Comparative metabolism of L-methionine, DL-methionine and DL-2-hydroxy-4methylthiobutanoic acid by broiler chicks. British Journal of Nutrition 54, 621-633.

Saunderson, C. L. \& Whitehead, C. C. (1987). $N^{\top}$-methyl histidine excretion and $\left[\mathrm{U}-{ }^{14} \mathrm{C}\right]$ amino acid oxidation in fully fed chickens from lines selected for high and low body-fat contents. Comparative Biochemistry and Physiology 86B, 419-422.

Tabor, H. (1962). Histidine degradation (formiminoglutamic acid metabolism). Methods in Enzymology 5, 784-790.

Tabor, H., Silverman, M., Mehler, A. H., Daft, F. S. \& Bauer, H. (1953). L-Histidine conversion to a urinary glutamic acid derivative in folic-deficient rats. Journal of the American Chemical Society 75, 756-757.

Whitehead, C. C. \& Bannister, D. W. (1978). Blood pyruvate carboxylase activity as a criterion of biotin status in chickens and turkeys. British Journal of Nutrition 39, 547-556. 